\title{
Recreation Potential in Ādaži Village
}

\author{
Una Kancāne, Una Île, Latvija University of Agriculture
}

\begin{abstract}
The desire of inhabitants to choose their residence in Pierīga has become increasingly popular which is proved by the growing number of population in Ādaži municipality. Since 2005 the number of population in Ādaži municipality has increased by $26 \%$. According to the Central Statistical Bureau of Latvia, 10,897 residents were declared in Ādaži municipality on January 1, 2016 [1]. Not only a permanent growth of the number of population has been observed, but also here is the largest share of young people until the age of 15 . Active recreation infrastructure has been established in Ādaži municipality, but it is insufficient due to a rapid growth of the number of population in recent years. The research explored development opportunities of cycling routes in the municipality. Besides, current active recreation provision for children and youth in

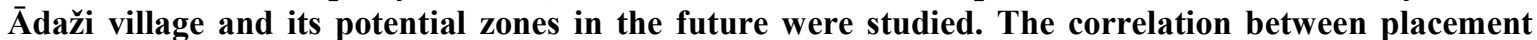
of active recreation zones and residential zones was analysed in order to determine the potential of active recreation in the public outdoor space.
\end{abstract}

Keywords: public outdoor space, active recreation, infrastructure

\section{Introduction}

A daži municipality is located in the northeast part of Pierīga region. The municipality borders on Garkalne, Carnikava, Saulkrasti, Sējas and Inčukalns municipalities. The municipality comprises 12 villages, out of which Ādaži, Kadaga, Baltezers and Garkalne are the largest ones. The administrative centre of the municipality is situated in Ādaži village. The subject of the research is Ādaži village, the centre of Ādaži municipality, which provides for the largest part of the infrastructure in the municipality. The territory has experienced several territorial reforms after the restoration of the Republic of Latvia. In 1997 part of Bergi, Garkalne and Vangaži villages was added to Ädaži. Ādaži village was transformed to a parish before 1991, but the present borders were fixed in 1992, when Carnikava parish was separated from Âdaži parish. In the framework of the administrative territorial reform in 2006 Ādaži parish was renamed Ādaži municipality without any changes of boundaries [2]. Ādaži village, the centre of Ādaži municipality, is located approximately $25 \mathrm{~km}$ from Riga centre; Highway A1 Rīga - Ainaži - Tallina connects it with Riga city. A positive feature for active recreation is the nearby location of two public beaches $-10 \mathrm{~km}$ distance to Carnikava beach and 20 $\mathrm{km}$ to Saulkrasti beach [3]. Consequently, the scheme was worked out on the basis of the infrastructure information taking into account theories on routes in the public outdoor space. One of the main conditions of a healthy way of life is walking, cycling or going by public transport which are healthy and environmentally friendly. J. Gehl, a Danish architect, considers that a comfortable city for a resident is if any destination is reachable in 5 minutes time on foot [4]. A person moves with the speed of $5 \mathrm{~km}$ per hour, it means that
400 metres is possible to cover in 5 minutes on foot. Thus to achieve the aim of the research, and to determine the active recreation potential for children and youth in Ādaži village, the accessibility of playgrounds was studied and analysed in Ādaži village. The potential of active recreation zones was determined during the research in relation to their accessibility radius from residential zones to the potential recreation zones within the territory of Ādaži village.

\section{Materials and Methods}

The research of active recreation opportunities in Ādaži village was conducted in the time period from August 2016 to March 2017. The literature review included the study of publications, electronic resources, space landscape analysis. To achieve the aim, the current situation was studied and analysed in Ādaži village. In addition, the inventory of playgrounds by Ivetas Grīvina, a spatial development planner, as of 2014 in Ādaži village as well as the information regarding the ownership rights, current structural elements, maintenance of facilities, and the analysis of fun equipment according to users' age group were used to determine potential recreation places. The monographic or descriptive method was used in the research.

\section{Results and Discussion}

In spring of 2016 Ādaži the municipality city council worked out the cycling concept which envisaged to develop cycling routes for regular (business) and recreational purposes with plans to integrate cycling routes in the overall traffic infrastructure of the municipality. The new concept envisaged to decrease the share of vehicles and change habits of the municipality residents in 


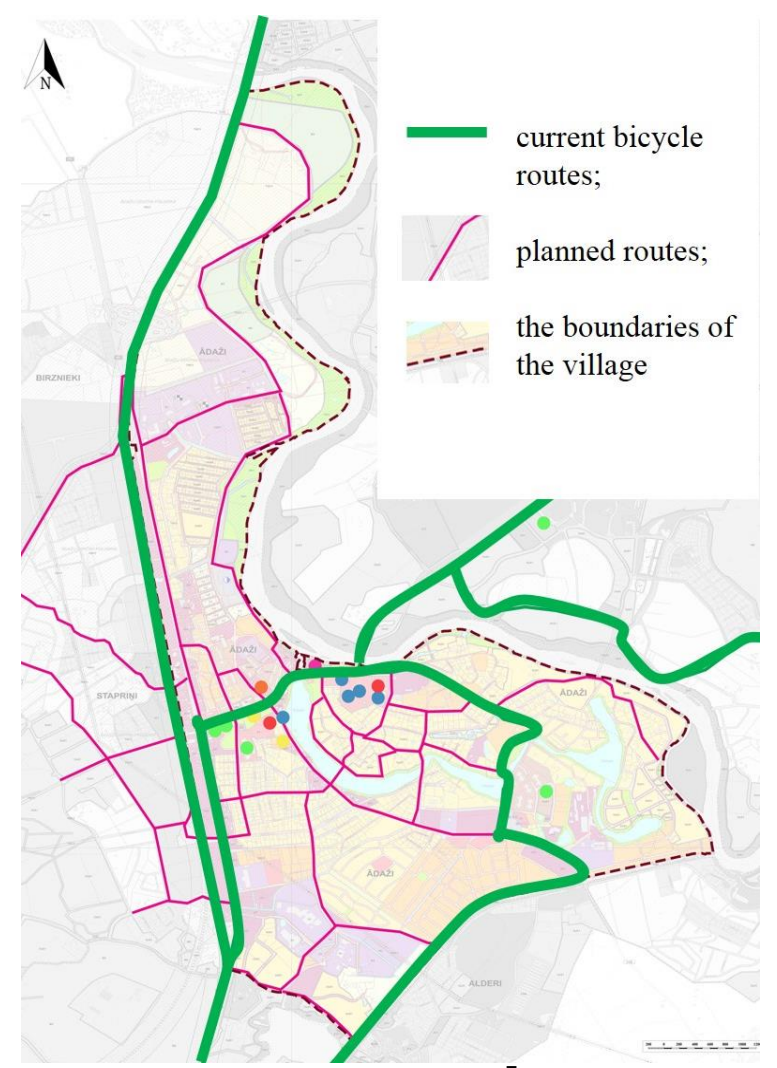

Fig. 1. Bicycle routes in Ādaži

[Source: The scheme made by the authors using the functional zoning scheme of Ādaži municipality]

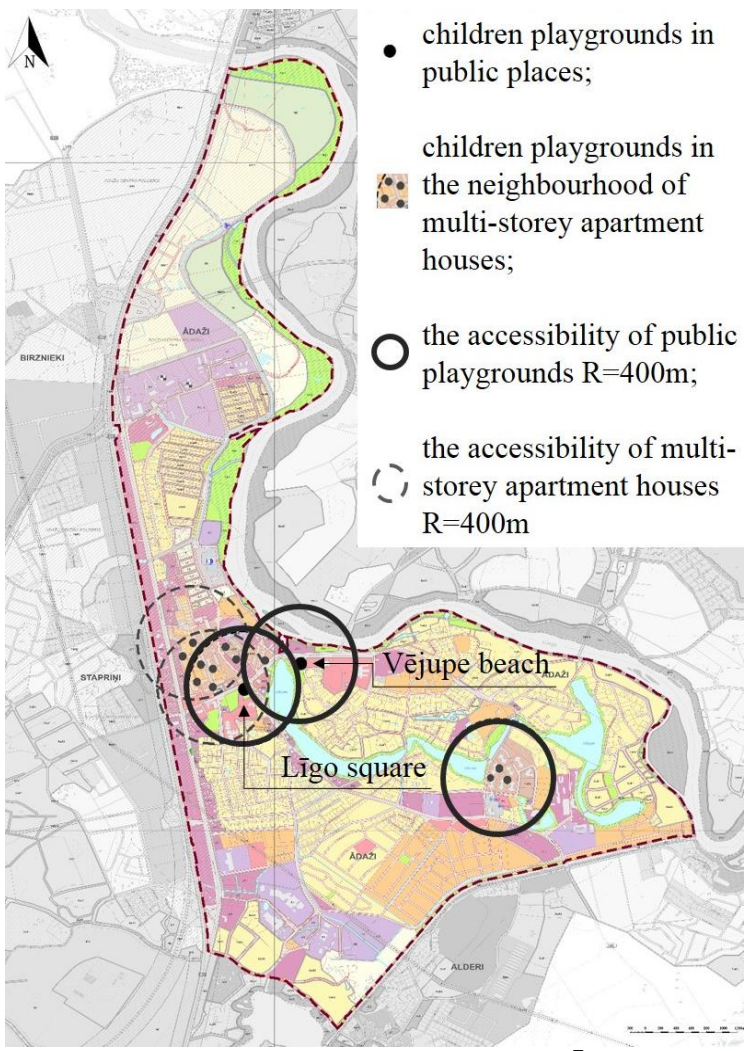

Fig. 2. The location of playgrounds in Ādaži

[Source: the scheme designed by the authors using the scheme of Ādaži functional zoning] reaching everyday destinations (schools, kindergartens, art and music schools, public institutions, shops, production units).

Creation of new cycling routes would promote cycling as part of active lifestyle especially among school children by establishing the net of bicycle routes from densely populated areas to education institutions and recreation places for young people. By increasing the recreation routes it would be possible to provide a comfortable access to recreation areas and to promote the municipality (see Fig. 1). Several business and recreation cycling routes were established for active recreation provision and more comfortable mobility in the municipality; there are also plans to expand cycling infrastructure in the municipality and connect the routes with those of neighbouring municipalities. Three bicycle routes were built in Ādaži municipality: No. 1: Ādaži - Dūņezers - Ādaži (25 30 km); No. 2: Ādaži - apkārt Mazajam Baltezeram - Ādaži $(15$ - 20 km); Nr. 3: Ādaži - apkārt Lielajam Baltezeram - Ādaži $(15-20 \mathrm{~km})$. Construction of cycling routes will continue. The following routes have been included in the development plans: Ādaži - Iḷķene - Old Peterburga road - National route 7; Ādaži - Carnikava beach Eiro Velo 13; Ādaži - Garciems beach - Eiro Velo 13 and others. The cycling society "ĀdažiVelo" actively arranges different cycling races and exciting family events [4].

The accessibility of playgrounds in Ādaži village may be divided into two groups: playgrounds in the territories surrounding multi-storey apartment houses and playgrounds constructed in public places (see Fig. 2). The comparison of the location of playgrounds and functional zoning of Ādaži village shows that playgrounds are mostly concentrated in the areas around multi-storey apartment buildings, and they are used by children of their residents. In 2014 Iveta Grīvina, a spatial development designer, carried out inventory of the current playgrounds which allowed the authors to conclude that each of the visited playgrounds had items of fun equipment suitable for children at the age from 4 to 10. As regards children from 10-12, there is one fun equipment at Līgo square (see Fig. 3). However, such service is provided for children of the area of private houses in the public playground of Vejupe beach, see Fig. 4. Playgrounds in the surroundings of multi-storey apartment houses have standard fun equipment installed on the lawn. At Lìgo square, items of mostly standard fun equipment are installed in washed sand coating, but the public playground unveiled in 2016 at Vejupe beach has interesting solutions for fun equipment, such as "sand factory", and "water games" which are meant for children from the age of 2 and "obstacle course" for children for the age from 4 to 10 . 
The information obtained during the inventory and the detailed information about maintenance companies, as well as the size of items of recreation equipment is summarized in Table 1.

Children playgrounds in the surrounding areas of multi-storied apartment houses create a feeling of private property, and they are far away from residential areas of private houses. Therefore children from private houses do not feel welcomed to use them and socialize with children from multi-storied apartment houses. This function is performed by public playgrounds at Lìgo square and Vējupe beach accessible for everyone, however, their capacity is not sufficient, besides the accessibility radius does not cover the largest part of private houses for children of all ages to use it simultaneously. The analysis of functional zoning of $\bar{A}$ daži village territory shows that public green zone accessible to general public account for $0.8 \%$ of the total area. To provide comfortable accessibility, the accessibility radius of 400 metres was taken as a benchmark for marking of potential zones in Ādaži village. The research selected potential territories for active recreation taking into account the current and planned nature zone and greenery. Consequently, three active recreation areas are suggested in order to provide wider opportunities and functions for active recreation in the planned future residential zones. The point is that active recreation zones should be installed before the design of residential zones.

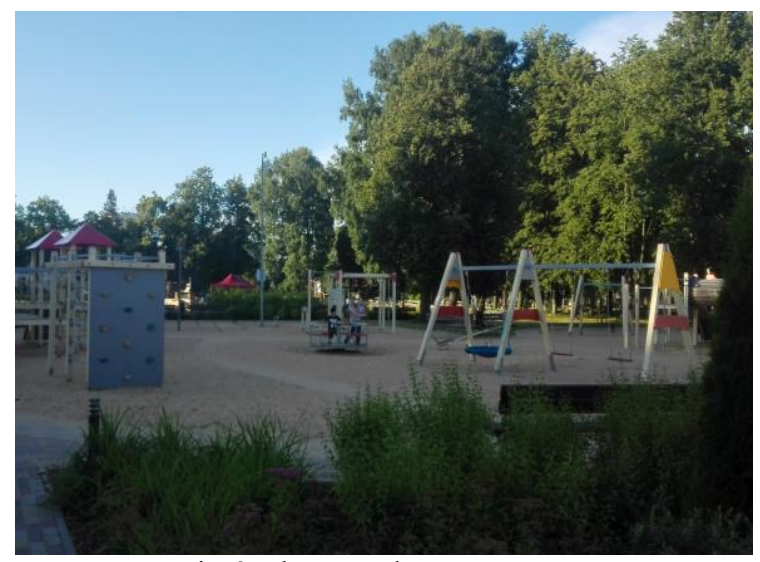

Fig. 3. Playgrounds at Ligo square [Source: U. Kancāne, 2017]

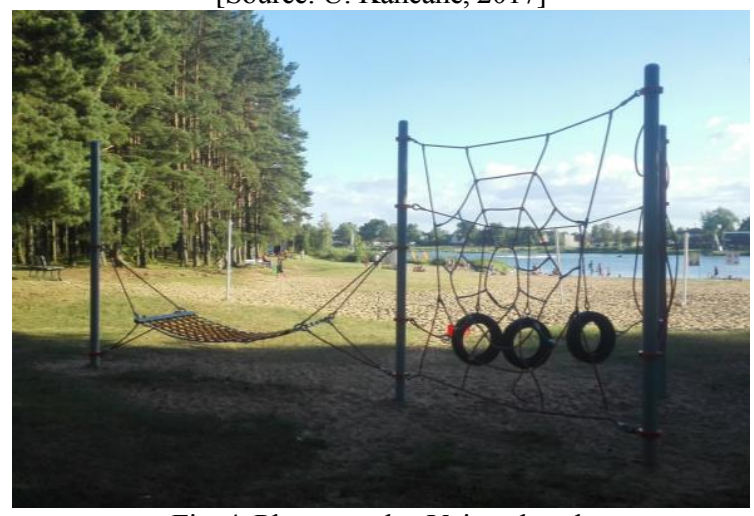

Fig. 4. Playground at Vējupe beach

[Source: U. Kancāne, 2017]

Children playgrounds in Ādaži municipality [Source: I. Grīvinna's materials]

TABLE 1

\begin{tabular}{|c|c|c|c|c|c|c|}
\hline \multirow[b]{2}{*}{ Address } & \multirow[b]{2}{*}{$\begin{array}{l}\text { Land ownership } \\
\text { rights }\end{array}$} & \multirow{2}{*}{$\begin{array}{c}\text { Responsible for } \\
\text { equipment } \\
\text { maintenance }\end{array}$} & \multicolumn{4}{|c|}{ Age groups of users } \\
\hline & & & $2-4$ years & 4-10 years & $10+$ years & $\begin{array}{c}\text { Sport } \\
\text { equipment }\end{array}$ \\
\hline $\begin{array}{c}\text { Attekas street } \\
20, \bar{A} \text { daži }\end{array}$ & $\begin{array}{l}\text { House owners } \\
\text { property }\end{array}$ & House owners & $\begin{array}{l}\text { Sandbox for } \\
\text { kids }\end{array}$ & Swing & - & - \\
\hline $\begin{array}{c}\text { Attekas street } \\
22, \bar{A} \text { Aaži }\end{array}$ & $\begin{array}{l}\text { House owners } \\
\text { property }\end{array}$ & House owners & $\begin{array}{l}\text { Wooden play } \\
\text { equipment }\end{array}$ & - & - & - \\
\hline $\begin{array}{c}\text { Gaujas street } \\
25, \text { Âdaži }\end{array}$ & $\begin{array}{c}\text { Municipality } \\
\text { property }\end{array}$ & Municipality & $\begin{array}{l}\text { Sandbox for } \\
\text { kids }\end{array}$ & $\begin{array}{l}\text { Playing town, } \\
\text { swing }\end{array}$ & - & - \\
\hline $\begin{array}{l}\text { Pirmā street } \\
\text { 21, Ādaži }\end{array}$ & $\begin{array}{l}\text { House owners } \\
\text { property }\end{array}$ & House owners & - & - & - & $\begin{array}{l}\text { Basketball } \\
\text { shields }\end{array}$ \\
\hline $\begin{array}{l}\text { Pirmā street } \\
29, \text { Àdaži }\end{array}$ & $\begin{array}{l}\text { Municipality } \\
\text { property }\end{array}$ & Municipality & $\begin{array}{l}\text { Sandbox for } \\
\text { kids } \\
\text { Swing }\end{array}$ & $\begin{array}{c}\text { Play town } \\
\text { playground } \\
\text { Swing, swing } \\
\text { balancer }\end{array}$ & $\begin{array}{l}\text { Climbing } \\
\text { equipment }\end{array}$ & - \\
\hline $\begin{array}{l}\text { Pirmā street } \\
\text { 30, Ādaži }\end{array}$ & $\begin{array}{l}\text { House owners } \\
\text { property }\end{array}$ & House owners & $\begin{array}{l}\text { Sandbox for } \\
\text { kids }\end{array}$ & $\begin{array}{l}\text { Playing } \\
\text { elements }\end{array}$ & - & $\begin{array}{c}\text { Mini } \\
\text { football }\end{array}$ \\
\hline $\begin{array}{c}\text { Pirmā iela 31, } \\
\text { Ādaži } \\
\end{array}$ & $\begin{array}{c}\text { Municipality } \\
\text { property }\end{array}$ & Municipality & - & - & - & $\begin{array}{c}\text { Basketball } \\
\text { hoop }\end{array}$ \\
\hline $\begin{array}{c}\text { Pirmā street } \\
\text { 33, Ādaži }\end{array}$ & $\begin{array}{l}\text { House owners } \\
\text { property }\end{array}$ & Municipality & $\begin{array}{l}\text { Sandbox for } \\
\text { kids }\end{array}$ & $\begin{array}{l}\text { Playing } \\
\text { elements }\end{array}$ & - & - \\
\hline $\begin{array}{l}\text { Ūbeḷu street } \\
\text { 13, Podnieki }\end{array}$ & $\begin{array}{c}\text { House owners } \\
\text { property }\end{array}$ & House owners & $\begin{array}{l}\text { Sandbox for } \\
\text { kids }\end{array}$ & Swing & - & - \\
\hline $\begin{array}{l}\text { Übelu street } \\
15, \text { Podnieki }\end{array}$ & $\begin{array}{l}\text { House owners } \\
\text { property }\end{array}$ & House owners & $\begin{array}{l}\text { Sandbox for } \\
\text { kids, } \\
\text { Kids slides }\end{array}$ & $\begin{array}{l}\text { Play town } \\
\text { with kids } \\
\text { slides, } \\
\text { swing, }\end{array}$ & - & $\begin{array}{c}\text { Exercise } \\
\text { equipment, } \\
\text { Balance } \\
\text { board, }\end{array}$ \\
\hline
\end{tabular}




\begin{tabular}{|c|c|c|c|c|c|c|}
\hline \multirow[b]{2}{*}{ Address } & \multirow[b]{2}{*}{$\begin{array}{l}\text { Land ownership } \\
\text { rights }\end{array}$} & \multirow{2}{*}{$\begin{array}{l}\text { Responsible for } \\
\text { equipment } \\
\text { maintenance }\end{array}$} & \multicolumn{4}{|c|}{ Age groups of users } \\
\hline & & & $2-4$ years & 4-10 years & $10+$ years & $\begin{array}{c}\text { Sport } \\
\text { equipment }\end{array}$ \\
\hline & & & & $\begin{array}{l}\text { large town } \\
\text { with nets }\end{array}$ & & $\begin{array}{l}\text { Volleyball } \\
\text { court }\end{array}$ \\
\hline $\begin{array}{l}\text { Ūbel̦u street } \\
\text { 16, Podnieki }\end{array}$ & $\begin{array}{l}\text { House owners } \\
\text { property }\end{array}$ & House owners & $\begin{array}{c}\text { Playing } \\
\text { equipment } \\
\text { with kids } \\
\text { slides, } \\
\text { Sandbox for } \\
\text { kids, } \\
\text { Game table } \\
\end{array}$ & - & - & - \\
\hline $\begin{array}{l}\text { Lazdu street } \\
5 \text {, Garkalne }\end{array}$ & $\begin{array}{c}\text { Municipality } \\
\text { property }\end{array}$ & Municipality & $\begin{array}{l}\text { Sandbox for } \\
\text { kids }\end{array}$ & $\begin{array}{l}\text { Playing } \\
\text { structure, } \\
\text { Swing }\end{array}$ & - & $\begin{array}{l}\text { Basketball } \\
\text { hoop }\end{array}$ \\
\hline Kadaga 5 & $\begin{array}{c}\text { Municipality } \\
\text { property }\end{array}$ & Municipality & $\begin{array}{l}\text { Sandbox for } \\
\text { kids }\end{array}$ & $\begin{array}{l}\text { Playground } \\
\text { structure with } \\
\text { kids slides, } \\
\text { Swing }\end{array}$ & - & $\begin{array}{l}\text { Volleyball } \\
\text { court }\end{array}$ \\
\hline Kadaga 6 & $\begin{array}{c}\text { Municipality } \\
\text { property }\end{array}$ & Municipality & $\begin{array}{l}\text { Sandbox for } \\
\text { kids } \\
\text { Swing }\end{array}$ & $\begin{array}{l}\text { Play town, } \\
\text { swing, swing- } \\
\text { balancer }\end{array}$ & $\begin{array}{l}\text { Climbing } \\
\text { equipment }\end{array}$ & - \\
\hline Kadaga 7 & $\begin{array}{l}\text { Municipality } \\
\text { property }\end{array}$ & Municipality & - & $\begin{array}{c}\text { Swing } \\
\text { (not working) }\end{array}$ & - & $\begin{array}{l}\text { Basketball } \\
\text { hoop, } \\
\text { exercise } \\
\text { equipment - } \\
\text { not usable }\end{array}$ \\
\hline Kadaga 9 & $\begin{array}{l}\text { Municipality } \\
\text { property }\end{array}$ & Municipality & $\begin{array}{l}\text { Sandbox for } \\
\text { kids }\end{array}$ & $\begin{array}{c}\text { Swing } \\
\text { balancer, } \\
\text { swing }\end{array}$ & - & - \\
\hline Kadaga 12 & $\begin{array}{l}\text { House owners } \\
\text { property }\end{array}$ & House owners & $\begin{array}{l}\text { Sandbox for } \\
\text { kids }\end{array}$ & $\begin{array}{c}\text { Swing, } \\
\text { balancer, } \\
\text { Kids slides, } \\
\text { climbing arch }\end{array}$ & - & $\begin{array}{l}\text { Ic hockey } \\
\text { rink }\end{array}$ \\
\hline Kadaga 13 & $\begin{array}{c}\text { Municipality } \\
\text { property }\end{array}$ & Municipality & $\begin{array}{l}\text { Sandbox for } \\
\text { kids }\end{array}$ & $\begin{array}{c}\text { Playing } \\
\text { structure }\end{array}$ & - & - \\
\hline $\begin{array}{c}\text { Lìgo square, } \\
\text { Âdaži }\end{array}$ & $\begin{array}{l}\text { Municipality } \\
\text { property }\end{array}$ & Municipality & $\begin{array}{c}\text { Play car, } \\
\text { Sandbox for } \\
\text { kids, } \\
\text { 4-seat swing } \\
\text { balancer, } \\
\text { swing } \\
\text { balancer (2) }\end{array}$ & $\begin{array}{c}\text { Complex } \\
\text { playground } \\
(2), \\
\text { Swing with } 3 \\
\text { swings, } \\
\text { balancer, } \\
\text { carousel, sport } \\
\text { equipment (2), } \\
\text { Rotating } \\
\text { carousel, } \\
\text { excavator }\end{array}$ & $\begin{array}{c}\text { Rope } \\
\text { pyramid }\end{array}$ & - \\
\hline
\end{tabular}

New areas for building private houses are indicated closer to Mazais Baltezers lake in the territorial zoning, however, the planned active recreational zone is located outside the village territory to provide a function for new areas of private houses. The functional zoning of Ādaži village envisages formation of multi-stories apartments in the neighbourhoods of Saule and Puku streets. Currently this territory comprises several private houses and agriculture land. The population growth is forecasted in this territory, therefore a potential active recreation zone was marked during the research, the radius of which includes neighbouring private houses and planned multi-storied apartment houses, see Fig. 5. The formation of an active recreation zone in this location would keep the green structure of the vicinity as well as provide residents with a publicly accessible area.

The second potential active recreation zone (Fig. 5., Zone No 2) would be located in the green zone of planned multi-storied apartment houses and private houses, it is located close to planned public building territory. Currently there is agriculture land, see Fig. 6. At present the territory of Zone No 3 (see Fig. 7) is covered by the forest. In order to maintain the landscape and its quality characteristic to the territory, it would be necessary to arrange a corresponding active recreation area. The design of this area should be carefully planned with preliminary inventory of trees with the focus on the 


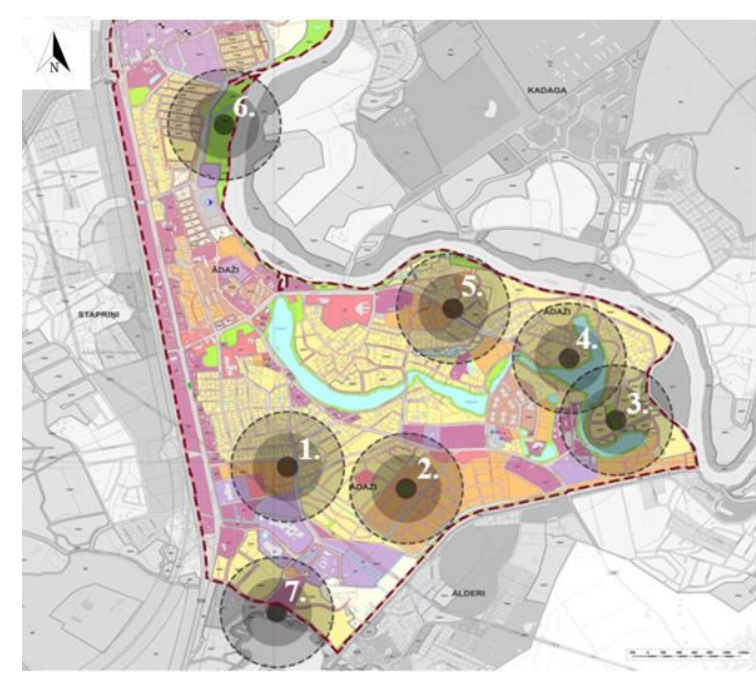

Fig. 5. Active recreation potential zones

[Source: the scheme created by the authors using functional zoning scheme of Ādaži municipality], 1 till 7 potential recreation places and active recreation zones; accessibility is $\mathrm{R}=400 \mathrm{~m}$

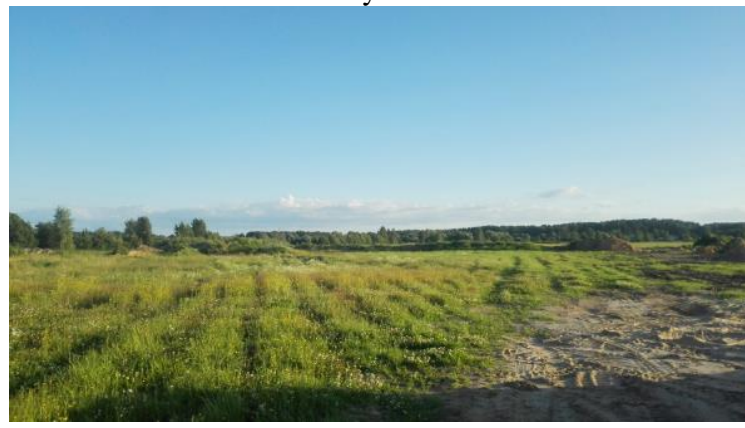

Fig. 6. Agricultural land as the potential Zone No 2 [Source: U. Kancāne, 2017]

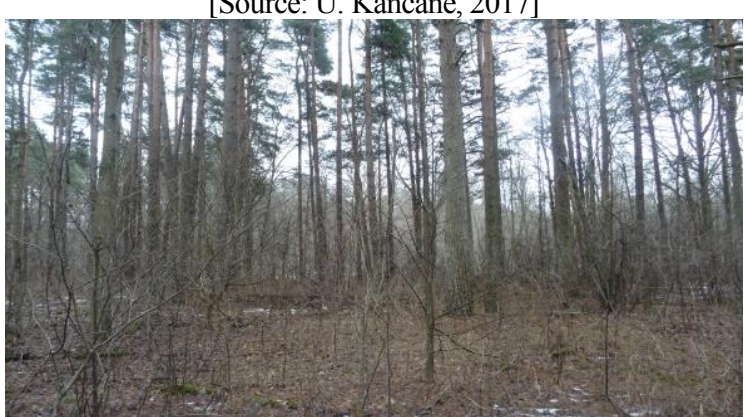

Fig. 7. Potential zone No. 3 for formation of an active recreation area [Source: U. Kancāne, 2017]

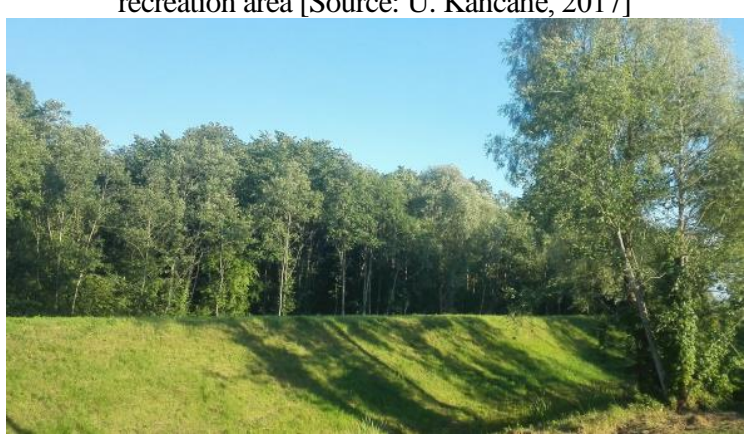

Fig. 8. The present scene to the Gauja behind the scrubs. Potential Zone No 6 for creating a publicly accessible recreation area [Source: U. Kancāne, 2017] forest area by integrating well-thought structural elements and adjusting relevant design linked with forest images. Thus it would be possible to achieve a specific place identity and integrate innovative design in the public outdoor space.

The fourth potential area No 4 currently is agricultural land, and it is located on the bank of Vejupe (Fig. 5, Zone No 4). As it is seen both in the current and planned zoning, this territory is envisaged for building private houses. A close distance of water is especially attractive for residents therefore it is possible to develop this place as a swimming place. It would be necessary to clean the bank of the river from scrubs, regular mowing would create a beautiful scene of the river and would provide access to the water.

As regards Zone No 5, the zone between two streets, Gauja and Skujas (see Fig. 5), is currently managed only by means of mowing the grass as it is surrounded by a large area of privately owned houses. The development of active recreation opportunities in the area would encourage neighbours to communicate, socialize and use public outdoor space of good quality for recreational activities.

The sixth potential territory has been selected in the region of Ādaži manor (Fig. 5, Zone No 6). The inspection of this territory allows to conclude that they are badly maintained and cleaned. These are private territories having signs created by residents themselves: "Private property, do not throw out litter", see Figures 8 and 9. The place would acquire the new identity if someone cleaned this area thus revealing a wonderful scene to the river line. Then residents would be more concerned about the order and cleanliness in this public outdoor space. The analysis of the relief and security of the place suggests that it is possible to develop modern and innovative attractive and accessible public outdoor space.

The seventh potential area has been selected outside the territory of Ādaži village (Fig. 5. Zone No 7), however, it is located in Ādaži municipality. Thus it would expand and form the link among the residents of municipality with different active and recreational opportunities and modern solutions in the public outdoor space. Since the territorial planning envisages development of the territory of private houses, the evaluation of the needs for active recreation zones suggests that the residential area of private houses could become more attractive with recreation places on the shore of Maizais Baltezers lake, see Figure 10. 


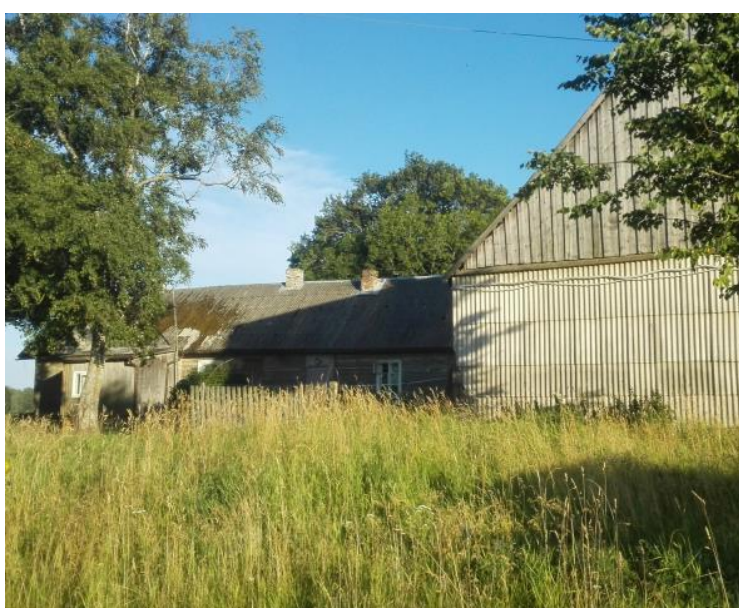

Fig. 9. The territory of Ādaži manor [Source: U. Kancāne, 2017]

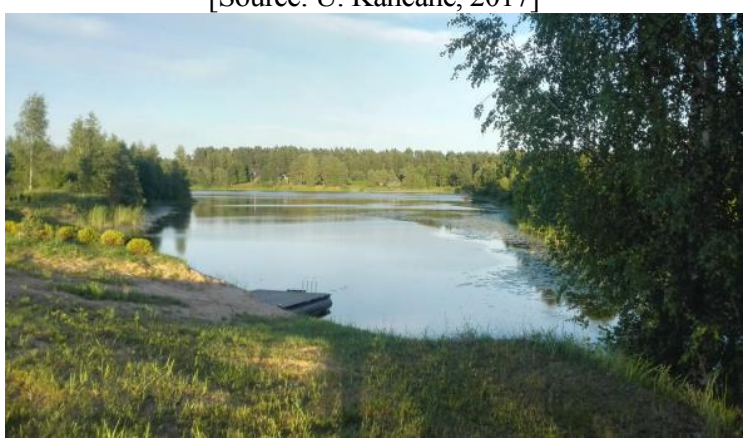

Fig. 10. The shore of Mazais Baltezers lake for development of Recreation Area No 7

[Source: U. Kancāne, 2017]

\section{Conclusions}

In Ādaži village there are 12 children playgrounds in the areas surrounding multi-story apartment buildings and 2 playgrounds in the public places, Līgo square and Ādaži beach, for provision of active recreation of children at the age from 0 to 12 years. Children playgrounds in the surrounding areas of multi-story apartment houses create a feeling of private property and they are far away from residential areas of private houses. Therefore children from private houses do not feel welcomed to use them and socialize with children from multi-story apartment houses. These functions are provided by playgrounds at Līgo square and $\bar{A} d a z ̌ i ~ b e a c h$, but their accessibility radius does not reach the majority of residential areas of private houses.

The designed plan of locations for the active recreation opportunities would provide residents with wider choice of recreation infrastructure in Ādaži village. The proposal of new zones was based on the principle of comfortable city planning which would offer easy accessibility to objects. Zoning of potential active recreation would keep the green zones in Âdaži village, besides, the territory management plan could include cleaning and improvement of these territories to become more user-friendly and secure for residents of Ādaži village.

\section{References}

1. 16 Latvijas novados audzis iedzīvotāju skaits [onlaine 1.06.2017.]. http://www.csb.gov.lv/notikumi/16-latvijasnovados-audzis-iedzivotaju-skaits-45208.html

2. Bauere, I. Ádaži. Novads un ḷaudis, Madona: Madonas poligrāfists, 2006, 208 lpp.

3. Ādažu novada dome, Ādažu novada attīitības programma (2016 - 2022). I sējums Esošās situācijas raksturojums [online 21.12.2016.]. http://www.adazi.lv/upload/attistibas_programma/attistibas_programma_i_dala_26.01.2016..pdf

4. Gehl, J. Cities for people, Washington, DC: Island Press, 2010, pp.19.-54.

5. Novada raksturojums [online 22.11.2016.]. http://www.adazi.lv/novads/novada-raksturojums/

Una Kancāne, landscape architect (since 2017), graduate Faculty of Rural Engineers, Department of Architecture and Construction of the Latvia University of Agriculture, 22 Liela iela, Jelgava, Latvia, LV-3001. From 2015-2016 study in Denmark, University of Copenhagen and Hungary, Corvinus University of Budapest. Research presented in $12^{\text {th }}$ International Scientific Conference "Students on Their Way to Science”. E-mail: una.kancane@gmail.com

Una İle, Dr. arch., Assist. Prof. (since 2012) at the Faculty of Rural Engineers, Department of Architecture and Construction of the Latvia University of Agriculture, 22 Liela iela, Jelgava, Latvia, LV-3001. E-mail: una.ile@1lu.lv

Kopsavilkums. Pētījumā izpētītas Ādažu novada mērogā veloinfrastruktūras attīstības iespējas. Savukārt, Ādažu ciemā - izpētītas bērnu un jauniešu aktīvās atpūtas nodrošinājums šobrīd un to potenciālās zonas nākotnē. Analizēta sakarība starp aktīvās atpūtas zonu izvietojumu un dzīvojamām zonām, lai noteiktu aktīvās atpūtas potenciālu ārtelpā. Pētījumā konstatēts, ka Ādažu ciemā bērnu aktīvās atpūtas nodrošināšanai vecuma grupā no 0-12 gadiem ir izveidoti 12 rotaļu laukumi daudzdzīvokḷu namu teritorijās un divi rotaḷu laukumi publiski pieejamās teritorijās - Līgo laukumā un Ādažu pludmalē. Izveidotie rotaļu laukumi daudzdzīvokḷu namu teritorijās rada privāta rakstura atmosfēru un ir lielā attālumā no savrupnamu teritorijām, tādā veidā liedzot bērniem no savrupnamu teritorijām tos izmantot, socializēties ar bērniem no daudzdzīvokḷu namu teritorijām. Šādas funkcijas nodrošina Līgo laukuma un Ādažu pludmales rotaḷu laukumi, kuru sasniedzamības rādiuss neaptver lielāko dalı savrupnamu teritorijas. 